\title{
Alma Ata: Reflections and future prospects in family health strategy
}

\author{
Alma Ata: reflexos e perspectivas futuras na \\ Estratégia Saúde da Família
}

Marcia MARINHO1 iD https://orcid.org/0000-0002-3567-8140
Sonia GROISMAN' ID https://orcid.org/0000-0003-1153-3841

\section{ABSTRACT}

The International Conference on Primary Health Care, held in Alma Ata, was one of the most significant public health events in the world, where for the first time the dependency between poverty and health status was discussed and measured. Even after 40 years of its implementation, it continues to influence directly public policies related to the principles of primary care. The aim of the present study was to carry out a review of literature based on PubMed / Medline, Virtual Health Library (BVS / Bireme / WHO-PAHO) and institutional documents of Brazilian Ministry of Health, in order to point out reflections of perceptions about Alma Ata Conference, in Brazilian public policies, tracing an evolutionary profile to the family health strategy and its future perspectives. Although the study found a strong influence of the Alma Ata Conference in Brazilian public health policies it still needs improvement to reach the global goals and objectives agreed by all countries in Alma Ata and reaffirmed in the World Health Organization's 2030 Sustainability Agenda.

Indexing terms: Family health strategy. Primary health care. Public health.

\section{RESUMO}

A Conferência Internacional sobre Atenção Primária de Saúde, realizada em Alma Ata, foi um dos eventos mais significativos para saúde pública a nível mundial, onde pela primeira vez se pontuou a dependência entre pobreza e estado de saúde. Mesmo após 40 anos de sua realização, continua influenciando e direcionando políticas públicas que vão evoluindo sem abandonar os princípios da atenção primária. O objetivo do presente trabalho foi realizar uma revisão de literatura pautada no PubMed/Medline, Biblioteca Virtual em Saúde (BVS / Bireme / OMS-OPAS) e em documentos institucionais do Ministério da Saúde do Brasil, com o intuito de pontuar os reflexos dos preceitos da Conferência de Alma Ata nas políticas públicas brasileiras, traçando um perfil evolutivo até a estratégia saúde da família e suas perspectivas futuras. O estudo constatou forte influência dos preceitos da Conferência da Alma Ata nas políticas públicas de saúde brasileira, mas que ainda necessitam de aprimoramento para alcançar as metas e objetivos globais traçados pela Alma Ata e repactuados na Agenda de Sustentabilidade para 2030 da Organização Mundial da Saúde.

Termos de indexação: Estratégia saúde da família. Atenção Primária à Saúde. Saúde pública.

\footnotetext{
$\checkmark v \nabla v$

1 Universidade Federal do Rio de Janeiro, Faculdade de Odontologia, Departamento de Odontologia Social e Preventiva. Av. Carlos Chagas Filho, 373, $2^{\circ}$ andar, Bloco K, sala 56, Edifício do Centro de Ciências da Saúde, 21941-902, Cidade Universitária, Rio de Janeiro, RJ, Brasil. Correspondence to: M Marinho. E-mail: <marciafriasm@gmail.com>.

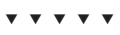

Marinho M, Groisman S. Alma Ata: Reflections and future prospects in Family Health Strategy. RGO, Rev Gaúch Odontol. 2020;68:e20200034. http://dx.doi.org/10.1590/1981-863720200003420190051
} 


\section{INTRODUCTION}

The restructuring of the Brazilian Unified Health System to achieve the principles of universality, wholeness and equity, organized among the three spheres of public services management (federal, state and municipal), has changed the focus of individual centered health care and curative actions of treatment, to a conception centered at the families and in the communities in order to promote; protect; cure and recover health. This restructuring was a result of Alma Ata Declaration: "Health for All in the Year 2000" and The First International Conference on Primary Health Care, open the discussion about the interaction between poverty and health status, aiming to decrease inequalities among people from different nations [1].

The implementation of Primary Health Care by federal governments was formulated by policies, strategies and action plans, based on universal accessibility, equity and social justice [1]. After Alma Ata, many of other conferences on Health Promotion were organized. For instance, The Letter of Ottawa, in 1986, proposed that governments should increase Health Promotion, in order to improve health changes in developed countries. In these Conference, Health Promotion, was defined as "the process of enhancing individuals and communities' capacities to control their health in order to improve it. To achieve a state of complete physical, mental and social wellness, the individual or the group must be able to identify and fulfill their aspiration and their needs, and modify or adapt to the environment" [2].

In Brazil, Family Health Strategy and the Brasil Sorridente, were implemented and adapted to each territory, according epidemiological profiles; demographic changes, migrations, new diseases and resurgence of old threats, such as natural catastrophes, health services capacities migration and economic cities possibilities.

According Pan American Health Organization (PAHO), social and medical actions should be adapted to the socioeconomic, health and cultural aspects of each community in order to promote, maintain and recover health, since it is a global public goal where oral health could not be dissociated from health.

At the 25 anniversary of Alma Ata, a policy of Health Promotion focused on Primary Care in the Americas with Social Responsibility has emerged, contributing to the oral health goals for 2010 and the Millennium Development Goals established by PAHOMHO, in 2025.

\section{METHODS}

The present study was a literature review based on PubMed/Medline database, Virtual Health Library (BVS/ Bireme/OMS-PAHO) and institutional documents Brazilian Ministry of Health.

\section{RESULTS}

In 1978, the International Conference on Primary Health Care resulted in the Alma Ata Declaration, introduced the concept of health as the state of complete physical, mental and social wellness, instead of absence of disease, and established a global goal, to be achieved by the year 2000, of acceptable levels of health for all, mainly through basic care, which represents the first level of contact with the national health system of individuals, families and communities, offering preventive; curative; rehabilitation and health promotion actions [1,2].

The Alma Ata Declaration assumed the inclusion of social justice perceptions in health planning, with the provision of care as close as possible to where people live and work to improve service assistance. In the two decades after Alma Ata, the neoliberal macroeconomic and social policies led to a structural adjustment, with dramatic cuts in public resources, resulting in chronic underfinancing of public health infrastructure, reducing health human resources, and, consequently, reducing people's access to health care [3].

XXI Century's first decade showed a huge disparity in health systems, stating the health polarization in developed countries. Therefore, there is a need to redirected health policies to act according to Primary Attention to Health principles [4].

The goals for 2025, as recommended at the Alma Ata Conference, reaffirmed in Millennium Development Goals, described and agreed upon by PAHO [5], included:

1. Poverty and hunger erradication.

2. Achieving universal primary education.

3. Promoting gender equality and women's authonomy.

4. Reducing children under 5 years' mortality.

5. Improving maternal health.

6. Combating HIV / AIDS, malaria and other diseases.

7. Ensuring the sustainability of the environment. 
8. Encouraging global partnership for development.

On the 30th anniversary celebration of Alma Ata, the World Health Organization published the Report "Primary Health Care Now More Than Ever," urging all governments to reflect on the principles of reform, since most of the goals listed in the 1978 Declaration had not been fulfilled. This reconfiguration of the system, establishing long-term preventive goals, was based on four fundamentals:

1) Universal access and social protection.

2) Reorganization of the services provision according to the population's expectations.

3) Renewing public policies that ensure healthier communities.

4) Optimizing management effectiveness with leadership reforms based on negotiation and participation, more appropriate to the current health system complexity [6].

In the third decade after the Alma Ata, though, the priority goals for maternal, neonatal and youth health and HIV, tuberculosis and malaria control were not implemented in accordance with outlined goals [3]. For the first time, surgery procedures were included in "primary care as a coordination center" by the World Health Organization [7].

As a gradual Evolution of Alma Ata Declaration, new goals have emerged, such as the United Nation Agenda 2030 for Sustainable Development, which renewed the commitment offering Universal Health Coverage, with universal health care access and high-quality treatment, reflecting in the 2015 World Health Assembly (WHA) actual resolution, that insert the emergency and surgical care as components of Universal Health Coverage [7].
Alma Ata became the fundamental basis of public health in Brazil, and influenced the Family Health Strategy (FHS) implemented in 1994, adapting to local epidemiological status and demographic transitions [3], based on local needs, using active search for treating and promoting health, as shown in figure $1[2,8]$.

The fundamentals of Alma Ata brought the evolution, humanization and implementation of the FHS, influencing the National Oral Health Policy (PNSB) and the Smiling Brazil Strategy [9], establishing different actions for access oral health care. In 2006, the Basic Care Booklet for Oral Health was published in order to be a professional guidance, and, in 2008, the Manual on Oral Health Specialties. In 2018, the last edition so far published by Ministry of Health was: "Oral Health in the Unified Health System" [2].

World Health Organization and governments agreed in the Letters of Health Promotion [10], creating goals also for oral health in 2010, as described by Narvai and illustrated at Table 1 [11]:

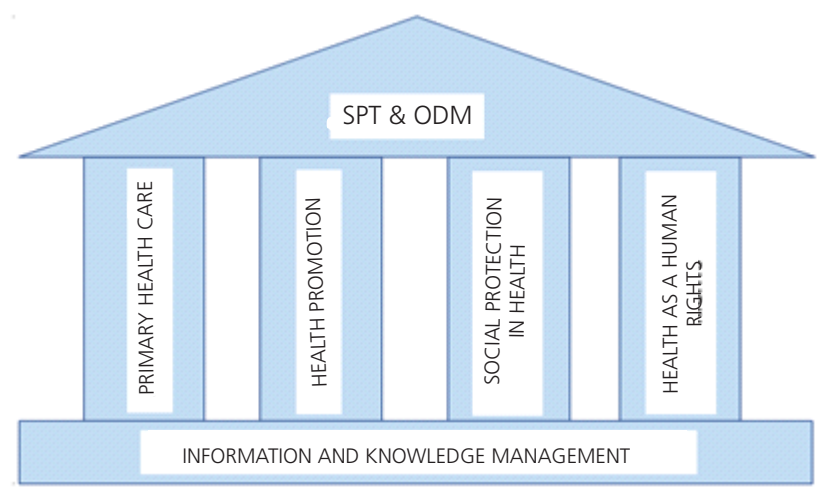

Figure 1. HEALTH = Public Health, with Social Policies.

Table 1. Goals for Oral Health in 2010, by Narvai.

\begin{tabular}{ll}
\hline AGE & GOAL \\
\hline 5 to 6 year-old children & absence of caries in $90 \%$ \\
12 years old & CPOD under 1 \\
15 years old & no more than 1 sextant with CPITN 1 or 2 \\
0 to 18 years old & No dental losses due to caries or periodontal disease \\
35 to 44 years old & No more than $2 \%$ edentulous \\
35 to 44 years old & $96 \%$ of people with at least 20 functional teeth \\
35 to 44 years old & No more than 0.25 sextant with CPITN of 4 \\
65 to 74 years old & Not more than $5 \%$ edentulous \\
65 to 74 years old & No more than 0.50 sextant with CPITN of 4 \\
\hline
\end{tabular}


In order to achieve these goals, it was necessary to train the oral health team as well, given a different education in dental schools focus towards health promotion, and integrated people from communities in their own development [12]. Facing the need of new professional training and permanent education of current working professionals, the National Curricular Guidelines Law was approved in 2001, listing the principles and guidelines of dentists to work in Health Unique System (HUS) as fundamental [13], to prepare the scientific and technical fields for the new definition of oral health of the International Dental Federation [14], which was defined as:

"Oral health is multifaceted and includes the ability to speak, smile, smell, taste, touch, chew, swallow and transmit a range of emotions through facial expressions with confidence and without pain, discomfort and craniofacial complex disease. Other attributes related to the definition state that oral health is a fundamental component of health and physical and mental wellness. It exists through a continuum influenced by the values and attitudes of individuals and communities; it reflects the physiological, social and psychological attributes essential to quality of life; it is influenced by the individual's experiences, perceptions, expectations and adaptability to circumstances". (p. 1, 2018)

Bispo Junior [9] describing the relevance of continued health professional educations, pointed out its relevance and that it should be seen, as a permanent process for health promotion by health professionals, that needs to receive constant reinforcement of health promotion, throughout the professional life, allowing the growth of knowledge and the applicability of scientific concepts to local social reality. Bispo Junior also described the relevance of the graduation courses be given in a more open, broad and interdisciplinary away in order to guarantee the proper qualification, that allowed solid basis for the constant acquisition of knowledge by the professionals, in the Family Health Strategy $[8,13,15]$.

The sum of the paradigm shifts from a disease to a holistic clinical care one, that could be only achieved by the alteration of curricular format, through Curricular Guidelines that emphasis concepts of health promotion; HUS principles and guidelines; teaching-learning with broad curricular integration; freedom and ability to work in multidisciplinary groups, with quality and resolution. These are some of the crucial factors for the achievement of the outlined aims, what is corroborated by several authors $[8,13,15]$.
In Brazil, health programs guidelines and goals are presented in the Pluriannual Plan, to establish quantitative indicators, that reflects the concept of health professional actions and practice in order to achieve efficiency in public administration [16] and transforming knowledge into oral health and health practices by the communities [9].

In Rio de Janeiro City, ten years after the insertion of the Oral Health Teams into the Family Health Strategy, population coverage of basic oral health teams has reached $22.32 \%$ in 2010/December, increasing to $30.57 \%$ in 2017/December [17], and that is in accordance with the International Dental Federation (IFD), that encouraged population to value their oral health and play an active role in assessing their needs, empowerment, as well oral health professionals, who should work with a broader vision of community, rather than dealing exclusively with the disease itself, besides, globally National Dentistry Associations have agreed that, in the future, oral health data should be used as an advocacy tool for national policymakers [18].

In the case of Rio de Janeiro city, data on population coverage by the basic oral health teams show a growth in the number of families assisted in Primary Care of Oral Health, although the goal idealized in 1978 is far from being reached. The population coverage of the Oral Health Teams increased from $22.32 \%$ to $30.57 \%$ [17] in the period from 2010 to 2017. In the same period, coverage of the Family Health Program increased from $30.61 \%$ to $70.89 \%$, reaching the goal set in the Pluriannual Plan 2014-2017, from $71 \%$ to $2017[17,19]$.

\section{DISCUSSION}

Alma Ata stated the universality access to primary health care and literature is unanimous about the benefits of health promotion for the world and Brazilian population $[1,3,4,6,20,21]$. Authors also corroborate that imperative factors to achieve international goals are due to human and financial resources that restricts its effectiveness as the basis of the Family Health Strategy [3,6,9].

Other factors described as obstacles to effectiveness of the Family Health Strategy are: urban violence in the FHS territories and the high turnover of health professionals. It is up to the managers to look for practical solutions to keep the professionals in their areas of activity and offer also training programs for them to be able to identify and adopt self-protection measures, through security protocols 
for emergency cases of urban violence, as to reduce the vulnerability they are exposed to [22].

In Brazil, Alma Ata 40 years anniversary is celebrated with 30 years of HUS, which dichotomized the Brazilian public service offering, in a constitutionally assured way, health to all. The 12th Sergio Arouca National Conference: "Politicization of the Economy", aimed to change the behavior of social actors involved in the development process, proactively acting in favor of living welfare conditions, which include oral and general health, resulting in inequalities reduction and higher social inclusion, but a huge variety of problems were found in the distinct regions of the country, avoiding the governments to reach the aims and goals proposed. The Alma Ata Conference was, with no doubt, was a victory for public health policies that led to improvements in people living conditions, and continues to influence and direct public policies without abandoning the principles of primary care, such as Health Promotion and Social Responsibility, necessary to citizenship achievement.

\section{CONCLUSION}

Although the "Health for All" goal has not been achieved, the Alma Ata Declaration remains a mark in health, and reflects the public policies commitment to answering communities needs and expectations.

As an important intervention strategy, there is an urgent to implemented and reinforce permanent education for health professionals as well curriculum guidelines for under graduated students, based on the values of citizenship and justice, as advocated by the Conference of Alma Ata and reaccepted in the World Health Organization (UN) sustainability agenda of 2030, in order to health agents including dentists be able to understand their different social groups, as well as the responsibilities they assume in front of the population, as a citizen and as professional, acting integrally, multi and transdisciplinarily.

\section{Collaborators}

M MARINHO contributed to the implementation of the research, to the analysis of the results and to the writing of the manuscript. S GROISMAN contributed to the design of the research and revision of the manuscript.

\section{REFERENCES}

1. Meireles ACPR, Oliveira CC. Bioethics and global health: primary care as an instrument of social justice. Bioethics Journal. 2012;20(1):28-40. Disponível em: <http://hdl.handle. net/1822/19743>.

2. Brasil. Ministério da Saúde. Departamento de Atenção Básica. A Saúde Bucal no Sistema Único de Saúde. Brasília, DF, 2018 [citado 2019 Jan 10] . Disponível em: <https:// www.saude.rj.gov.br/comum/code/MostrarArquivo. php?C=MTY4NDk\%2C>.

3. Lawn JE, Rohde J, Rifkin S, Were M, Paul VK, Chopra M. Alma-Ata 30 years on: revolutionary, relevant, and time to revitalize. The Lancet. 2008; 372(9642):917-27. https://doi. org/10.1016/S0140-6736(08)61402-6

4. Gottero L. Primary health care. Neo-liberal continuities in "personcentered assistance". Health Sciences J. 2012;10(3):369-85.

5. Pan American Health Organization. Promoting Health in the Americas. Primary Health Care 25 years after the Declaration of Alma-Ata; 2004.

6. Soranz D, Pisco LAC. Primary Health Care Reform in the cities of Lisbon and Rio de in health in the city of Lisbon and Rio de Janeiro: context, strategies, results, learning, challenges. Science \& Health Collective. 2017; 22(3):679. https://doi. org/10.1590/1413-81232017223.33722016

7. Griswold DP, Makoka MH, Gunn SWA, Johnson WD. Essential surgery as a key component of primary health care: reflections on the 40th anniversary of Alma-Ata. BMJ Global Health. 2018; 3 (Suppl 3): e000705. http://dx.doi.org/10.1136/ bmjgh-2017-000705

8. Tatiane Aparecida Moreira Da S, Lislaine Aparecida F, Anna Maria C. Professional trajectory in the Family Health Strategy: focus on the contribution of specialization programs Professional trajectory in the Family Health Strategy: focus on the contribution of specialization courses Professional trajectory in the Family Health Strategy: in focus the contribution of the specialization courses. Revista LatinoAmericana de Enfermagem. 2011;19(1):148-55. http://dx.doi. org/10.1590/S0104-11692011000100020

9. Bispo JP, Moreira DC. Continuing education and matrix support: training, experience, and practices of health professionals in the Centers for the Support of Family Health and the supported teams. Public health notebooks. 2017;33(9):e00108116. https://doi.org/10.1590/0102-311x00 108116

10. Brasil. Ministério da Saúde. As Cartas da Promoção da Saúde. Brasília: MS, 2002 [citado 2019 Jan 10]. Disponível em: <www.saude.gov.br/bvs/conf-tratados.html>.

11. Narvai, C. P; Year IV - number 52 - First half of June 2002 - Are oral health goals for 2010? [citado 2019 Jan 10]. Disponível em: <http://www.jornaldosite.com.br/arquivo/anteriores/capel/ artcapel51.htm>.

12. Feliciano KVO, Kovacs MH, Costa IER, Oliveira MG, Araújo AMS. Continuing assessment of continuing education in child care in the family health strategy. Braz J Mat Child Health. 2008;8(1):45-53. https://doi.org/10.1590/S1519-38292008 000100006 
13. Silva VO, Santana PMMA. Curriculum content and the Brazilian Unified Health System (HUS): analytical categories, gaps and challenges / Curriculum content and the Brazilian Health System (HUS): analytical categories, gaps and challenges. Interface: Communication Health Educ. 2015;19(52). https:// doi.org/10.1590/1807-57622014.0017

14. Federation WD. Shaping the future of oral health. Disponivel em: <https://www.fdiworlddental.org/fdi-at-work/advocacy/shapingthe-future-of-oral-health>.

15. Costa D, Silva R, Lima V, Ribeiro E. National curriculum guidelines for health professions 2001-2004: an analysis according to curriculum development theories. Interface Communication, Health, Education; 2018. https://doi.org/10. 1590/1807-57622017.0376

16. Brasil. Prefeitura do Rio de Janeiro. Secretaria Municipal de Fazenda. Orçamento; 2019 [citado 2019 Jan 10]. Disponível em: <http://www.rio.rj.gov.br/web/smf/orcamento>.

17. Brasil. Ministério da Saúde. Informação e Gestão da Atenção Básica e-Gestor [citado 2019 Jan 10]. Disponível em:<https://egestorab.saude.gov.br/paginas/acessoPublico/ relatorios/relHistoricoCoberturaSB.xhtml;jsessionid=eb+Vlo5 ERWbEYjqsExe1skbR>.
18. Brasil. Ministério da Saúde. Secretaria de Gestão Estratégia e Participativa. Política Nacional de Gestão Participativa para o SUS - ParticipaSUS. Brasília: Ministério da Saúde; 2005.

19. Prefeitura do Rio de Janeiro. Plano Plurianual 2014/2017. Relatório de Gestão e Avaliação do Exercício 2016. [citado 2019 Jan 10]. Disponível em: <http://www2.rio.rj.gov.br/smf/ banco/pdforc/ppa/2014-2017/rel_gappa2016.pdf>.

20. Martín Zurro A. Alma Ata and family medicine: 40 years of crossing the desert. Primary Care. 2018;50(4):203-4. https:// doi.org/10.1016/j.aprim.2018.02.002

21. Nascimento AC, Moyses ST, Werneck RI, Moyses SJ. Oral health in the context of primary care in Brazil. Int Dent J. 2013;63(5):237-43. https://doi.org/10.1111/idj.12039

22. Comitê Internacional da Cruz Vermelha. Cidades brasileiras tomam medidas para reduzir impacto da violência em serviços públicos. Julho 2017 [citado 2019 Jan 10]. Disponível em: <https://www.icrc.org/pt/document/cidades-brasileirasmedidas-reduzir-impacto-violencia-servicos-publicos>.

Received on: 4/4/2019 Approved on: 13/5/2019 